\title{
Effect of Different Ageing Processes on Microstructure and Mechanical Properties of Cast Al-3Li-2Cu-0.2Zr Alloy
}

\author{
Guohua Wu ${ }^{1} \cdot$ Chunchang Shi ${ }^{1} \cdot$ Liang Zhang $^{1} \cdot$ Wencai Liu $^{1} \cdot$ Antao Chen ${ }^{1} \cdot$ Wenjiang Ding $^{1}$
}

Received: 20 December 2019 / Revised: 13 January 2020 / Published online: 21 April 2020

(c) The Chinese Society for Metals (CSM) and Springer-Verlag GmbH Germany, part of Springer Nature 2020

\begin{abstract}
The effect of different ageing processes on microstructure and mechanical properties of cast $\mathrm{Al}-3 \mathrm{Li}-2 \mathrm{Cu}-0.2 \mathrm{Zr}$ alloy was investigated using transmission electron microscopy and tensile tests. The results showed that the mean size of $\delta^{\prime}-\mathrm{Al}_{3} \mathrm{Li}$ particles and the number density of $\mathrm{Cu}$-rich precipitates both increased with increasing ageing temperature from 150 to $190{ }^{\circ} \mathrm{C}$ for $24 \mathrm{~h}$, resulting in increasingly high strength. In contrast, the ductility deteriorated with the increase in ageing temperature as a result of the intensified planar slip. The duplex low-to-high ageing treatment $\left(120^{\circ} \mathrm{C}\right.$ for $6 \mathrm{~h}$ followed by $160^{\circ} \mathrm{C}$ for $24 \mathrm{~h}$ ) was shown to be beneficial to the ductility compared with the corresponding single-stage ageing treatment $\left(160{ }^{\circ} \mathrm{C}\right.$ for $\left.24 \mathrm{~h}\right)$. The reduced slip length induced by the precipitation of $\theta^{\prime}-\mathrm{Al}_{2} \mathrm{Cu}$ phases was found to be mainly responsible for this ductility improvement.
\end{abstract}

Keywords Cast Al-Li alloy $\cdot$ Ageing treatment $\cdot$ Precipitates $\cdot$ Slip length

\section{Introduction}

The growing concern over the energy and environment issues has considerably increased the demand for lightweight structures in automobile, aerospace and marine industries [1]. Al-Li alloys are regarded as a class of promising lightweight materials intended for structural applications [2,3]. Lithium is the lightest metallic element in nature $\left(M=6.94 \mathrm{~g} \mathrm{~mol}^{-1}\right)$ and one of the alloying elements that have a high solubility in aluminum as well. At the eutectic temperature, about $4.2 \mathrm{wt} \%$ lithium can dissolve in aluminum [4]. It is well known that each $1 \mathrm{wt} \%$ increment of lithium addition to an aluminum alloy decreases the density by approximately $3 \%$, increases the elastic modulus simultaneously by about $6 \%$ and introduces precipitation hardening by the formation of metastable $\delta^{\prime}-\mathrm{Al}_{3} \mathrm{Li}$ phases $[5,6]$. All these three aspects lead to the weight reduction in structures

Available online at http://link.springer.com/journal/40195.

Liang Zhang

liangzhang08@sjtu.edu.cn

1 National Engineering Research Center of Light Alloy Net Forming and State Key Laboratory of Metal Matrix Composites, Shanghai Jiao Tong University, Shanghai 200240, China with a definite demand for mechanical properties. Under this circumstance, an increasing number of studies about Al-Li alloys have been carried out $[7,8]$.

Unlike the high solid solubility at the eutectic temperature, equilibrium lithium concentration in the aluminumbased solid solution at room temperature is only $0.39 \mathrm{wt} \%$ [9], which determines the age-hardening effect of Al-Li alloys and the existence of various Li-bearing precipitates. To further improve the strength, copper is usually added to $\mathrm{Al}-\mathrm{Li}$ alloys. The main strengthening phases such as $\delta^{\prime}-\mathrm{Al}_{3} \mathrm{Li}, \mathrm{T}_{1}-\mathrm{Al}_{2} \mathrm{CuLi}$ and $\theta^{\prime}-\mathrm{Al}_{2} \mathrm{Cu}$ precipitates have been widely studied in modern commercial $\mathrm{Al}-\mathrm{Li}-\mathrm{Cu}$ alloys [10]. It is well accepted that the superlattice $\delta^{\prime}$ phase has a $\mathrm{Cu}_{3} \mathrm{Au}$-type $\left(\mathrm{L}_{2}\right)$ cubic structure $(a=0.401 \mathrm{~nm})$ and the orientation relationship (OR) $(100)_{\delta^{\prime}}\left\|(100)_{\mathrm{Al}},[100]_{\delta^{\prime}}\right\|$ $[100]_{\mathrm{Al}}$ with $\mathrm{Al}$ matrix. The ternary $\mathrm{T}_{1}$ phase has the hexagonal lattice (space group P6/mmm, $a=0.496, c=0.935 \mathrm{~nm}$ ) with OR $(0001)_{\mathrm{T} 1}\left\|(111)_{\mathrm{Al}},[\overline{1010}]_{\mathrm{T} 1}\right\|[1 \overline{1} 0]_{\mathrm{Al}}$. In contrast, the metastable $\theta^{\prime}$ phase has the tetragonal lattice $(a=0.404$, $c=0.58 \mathrm{~nm})$ with OR $(001)_{\theta^{\prime}}\left\|(001)_{\mathrm{Al}},[100]_{\theta^{\prime}}\right\|[100]_{\mathrm{Al}}[9$, 11]. The addition of other elements including $\mathrm{Mg}, \mathrm{Ag}, \mathrm{Mn}$, $\mathrm{Zr}$ and Sc further complicates the precipitation path.

In addition to the composition, the microstructure of $\mathrm{Al}-\mathrm{Li}$ alloys was reported to be sensitive to the pre-age deformation and subsequent ageing process. Al-Li alloys are typically aged at $150-190{ }^{\circ} \mathrm{C}$ [12]. When exposed to a temperature higher 
than $200{ }^{\circ} \mathrm{C}, \delta^{\prime}$ precipitates are not stable and tend to dissolve [13]. Zhang et al. studied the ageing response of $\mathrm{Al}-\mathrm{Li}-\mathrm{Cu}$ AA2198 alloy and found this alloy exhibited strong ageing response upon T8 heat treatment [14]. At present, commercial Al-Li alloys such as the previous mentioned AA2198 are mainly wrought alloys in the shape of pipe, sheet or rod. The content of $\mathrm{Li}$ is generally lower than $1.8 \mathrm{wt} \%$ to avoid crack deviation [15]. Compared with wrought alloys, cast Al-Li alloys cannot only be used to manufacture isotropic products with complex shapes but also lead to a more effective weight reduction derived from the normally higher Li content [16, 17]. In our previous work [18], cast $\mathrm{Al}-3 \mathrm{Li}-x \mathrm{Cu}-0.2 \mathrm{Zr}(x=0$, $1,1.5,2,2.5,3)$ alloys were researched, and the optimum $\mathrm{Cu}$ addition of the studied alloy was confirmed as $2 \mathrm{wt} \%$ based on the analysis. As mentioned previously, apart from the composition design, the ageing process plays an important role in the manufacture of Al-Li alloys. The pre-age deformation is not suitable for cast alloys. Hence, the ageing response of cast $\mathrm{Al}-\mathrm{Li}-\mathrm{Cu}$ alloys is much different from wrought $\mathrm{Al}-\mathrm{Li}-\mathrm{Cu}$ alloys due to the lack of dislocations, which provide lowenergy nucleation sites for strengthening precipitates. However, limited information is available on the ageing-microstructure-property relationship of cast $\mathrm{Al}-\mathrm{Li}-\mathrm{Cu}$ alloys. In this study, we sought to clarify the influence of different ageing processes on microstructure and mechanical properties of cast Al-3Li-2Cu- $0.2 \mathrm{Zr}$ alloy. The results could be drawn upon to guide the preparation and application of cast $\mathrm{Al}-\mathrm{Li}-\mathrm{Cu}$ alloys.

\section{Material and Methods}

The $\mathrm{Al}-3 \mathrm{Li}-2 \mathrm{Cu}-0.2 \mathrm{Zr}$ alloy was prepared from commercial pure (CP) Al, CP Li, Al-50 wt\% Cu master alloy and Al-10 wt $\% \mathrm{Zr}$ master alloy at $750{ }^{\circ} \mathrm{C}$ using an electric resistance furnace under the protection of $\mathrm{LiCl}-\mathrm{LiF}$ flux mixture and argon atmosphere. The actual composition of the studied alloy, measured by inductively coupled plasma atomic emission spectroscopy (ICP-AES), is listed in Table 1. To give impetus to the ageing process, all samples were solution treated at $500{ }^{\circ} \mathrm{C}$ for $32 \mathrm{~h}$, followed by $560{ }^{\circ} \mathrm{C}$ for $24 \mathrm{~h}$ and quenched into cold water. Then the samples were aged at $150{ }^{\circ} \mathrm{C}$, $160{ }^{\circ} \mathrm{C}, 170{ }^{\circ} \mathrm{C}, 180{ }^{\circ} \mathrm{C}$ and $190{ }^{\circ} \mathrm{C}$ for $24 \mathrm{~h}$, respectively. Besides, a duplex ageing treatment at $120^{\circ} \mathrm{C}$ for $6 \mathrm{~h}$ followed by $160{ }^{\circ} \mathrm{C}$ for $24 \mathrm{~h}$ (hereafter named two-stage ageing, TS) was applied. In comparison, natural ageing sample at room temperature for 6 months (hereafter named natural ageing, NA) was also prepared. All artificial ageing treatments were

Table 1 Actual chemical composition of the investigated $\mathrm{Al}-3 \mathrm{Li}-$ $2 \mathrm{Cu}-0.2 \mathrm{Zr}$ alloy $(\mathrm{wt} \%)$

\begin{tabular}{llllll}
\hline $\mathrm{Li}$ & $\mathrm{Cu}$ & $\mathrm{Zr}$ & $\mathrm{Fe}$ & $\mathrm{Na}$ & $\mathrm{Al}$ \\
\hline 2.95 & 2.02 & 0.15 & 0.16 & 0.04 & $\mathrm{Bal}$ \\
\hline
\end{tabular}

conducted in an oil bath with temperature fluctuations less than $\pm 1{ }^{\circ} \mathrm{C}$ and terminated by immediate water quenching. To learn mechanical properties, tensile tests were conducted at a speed of $1 \mathrm{~mm} \mathrm{~min}^{-1}$ on a Zwick/Roell Z100 testing machine equipped with a non-contact extensometer. Transmission electron microscopy samples were prepared by a twin-jet polishing technique in a solution composed of 4 vol\% perchloric acid and 96 vol.\% ethanol, which was cooled down to approximately $-30^{\circ} \mathrm{C}$ by liquid nitrogen in the preparation process. Transmission electron microscopy (TEM) observation was conducted on a JEOL2100 microscope operating at $200 \mathrm{kV}$ and the tensile-ruptured surfaces of the studied alloy were observed using a scanning electron microscope (SEM, Phenom XL).

\section{Results and discussion}

\subsection{Microstructure}

The optical micrograph and SEM backscattered electron image of the as-cast alloy are shown in Fig. 1a, c, respectively. The microstructure consisted of dendritic $\alpha$ - $\mathrm{Al}$ grains and coarse intermetallic phases at grain boundaries. Based on the energy disperse spectroscopy (EDS) linear scanning result, these bright intermetallic phases were rich in $\mathrm{Cu}$ as shown in Fig. 1e, f. After the solution treatment $\left(500{ }^{\circ} \mathrm{C}\right.$ for $32 \mathrm{~h}$ followed by $560{ }^{\circ} \mathrm{C}$ for $24 \mathrm{~h}$ ), most intermetallic compounds were dissolved into the matrix, which can be observed in the optical micrograph (Fig. 1b) and SEM backscattered electron image (Fig. 1d) of the as-quenched alloy. The formation of the supersaturated solid solution in this solution treatment process can provide the impetus for the following ageing treatment.

Figure 2a, $\mathrm{b}$ shows the bright-field (BF, $B=[011])$ image and dark-field (DF) image of the sample subjected to NA treatment, respectively. As can be seen in Fig. 2a, a certain number of bean-like $\beta^{\prime}-\mathrm{Al}_{3} \mathrm{Zr}$ phases were dispersed in the matrix. This Ashby-Brown contrast feature proved the coherent relationship between $\beta^{\prime}$ phase and the $\alpha$-Al matrix. Figure $2 b$ indicates that quantities of ultra-fine $\delta^{\prime}$ phases were precipitated in the natural ageing process. After quenching, vacancies were trapped in solid solution. Condensation of vacancies took place over time at room temperature and the stored energy associated with the binding of lithium atoms to vacancies was released [19], which gave impetus to the precipitation of these fine $\delta^{\prime}$ particles. Some core/shell composite particles can also be observed besides $\beta^{\prime}$ and $\delta^{\prime}$ phases as shown in Fig. 2b. During solution treatment, precipitation of metastable $\beta^{\prime}$ phases occurred [20], initiating at about $450{ }^{\circ} \mathrm{C}$ [21]. These unevenly distributed particles could serve as heterogeneous nucleation sites for $\delta^{\prime}$ phases during the subsequent ageing process, leading to a "bull's eye" 

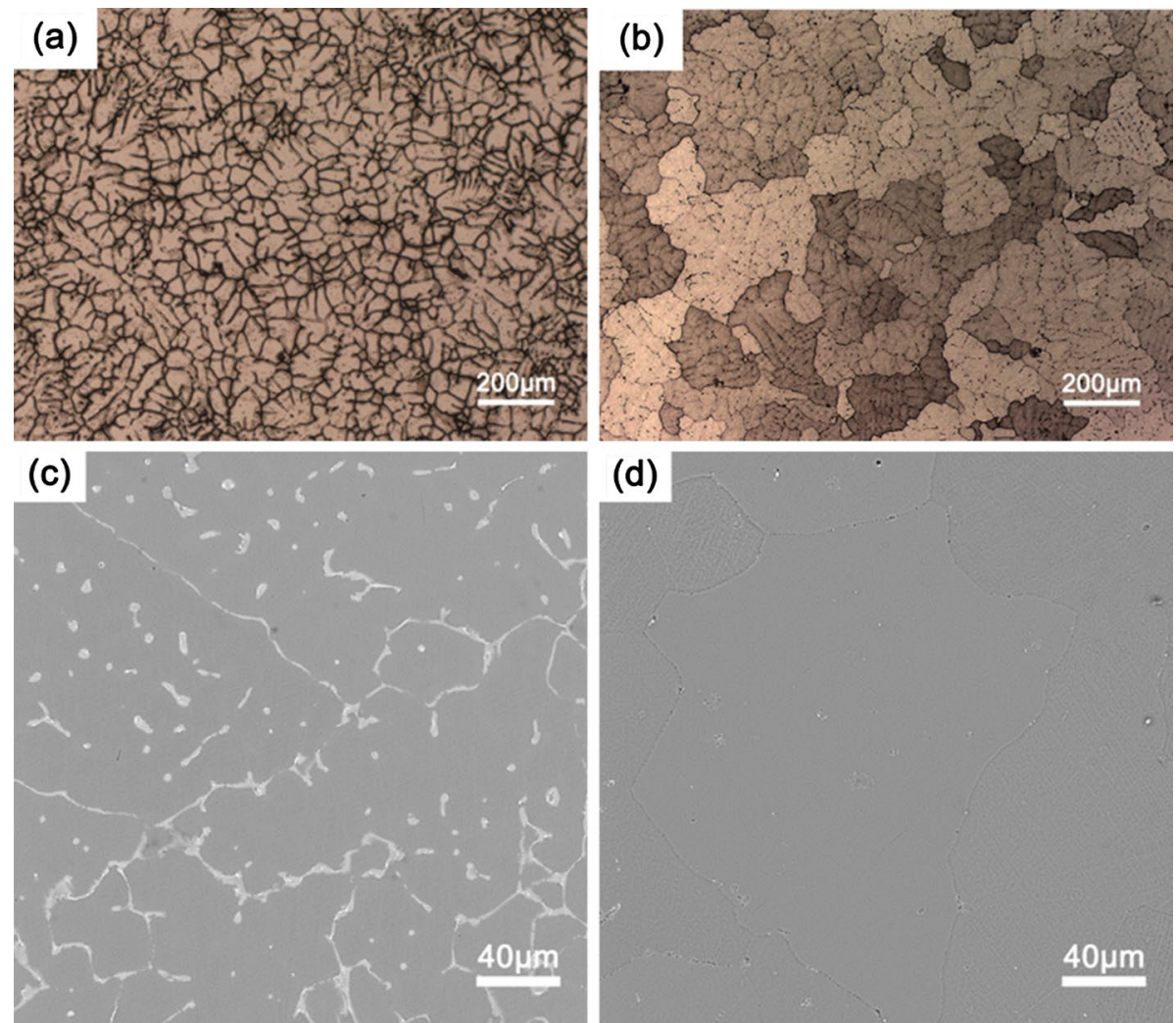

(d)

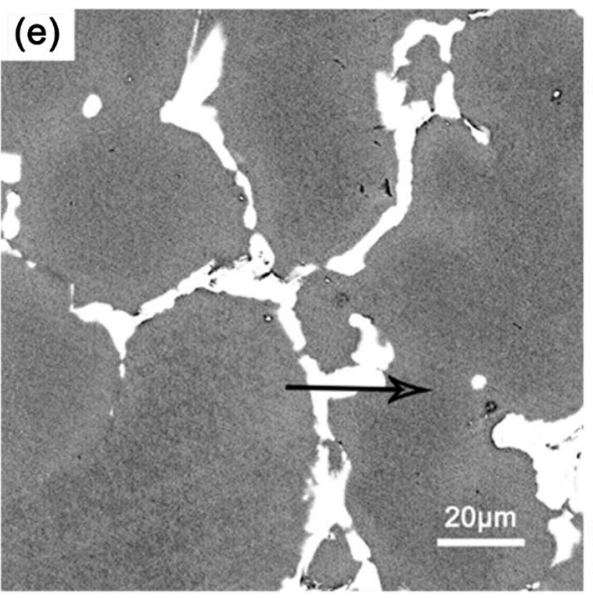

(f)
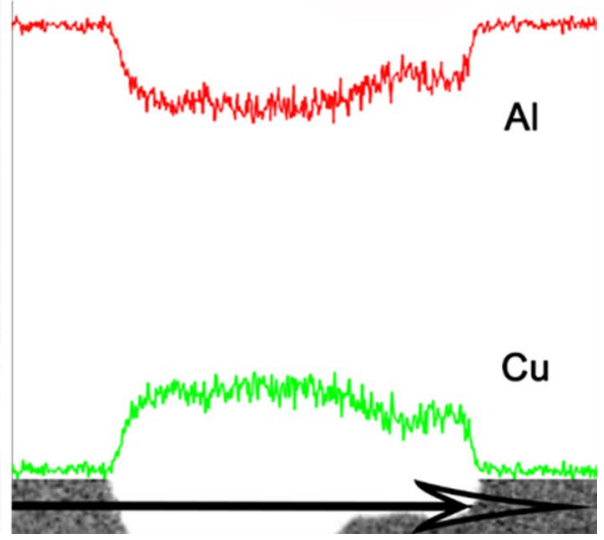

Fig. 1 Typical microstructures of the studied alloy: a OM image and $\mathbf{c}$ SEM backscattered electron micrograph of the as-cast alloy; $\mathbf{b}$ OM image and $\mathbf{d}$ SEM backscattered electron micrograph of the as-quenched alloy; e partial enlarged SEM image; $\mathbf{f}$ the corresponding $\mathrm{Al}, \mathrm{Cu}$ linear scan analysis of the as-cast alloy

structure with a $\beta^{\prime}$ core and a $\delta^{\prime}$ shell [15]. However, not any $\mathrm{Cu}$-rich particle was found because of the low precipitation kinetics in the naturally aged condition. This result is consistent with the previous research on AA2198 [14].

The typical BF micrograph $(B=[011])$ of the sample aged at $150{ }^{\circ} \mathrm{C}$ for $24 \mathrm{~h}$ is shown in Fig. 3a. A few plate-like precipitates were distributed unevenly in the matrix. The number density of these phases was about $2469.1 \mu \mathrm{m}^{-3}$. It is well known that the $\theta^{\prime}$ and $\mathrm{T}_{1}$ phases precipitate on $\{100\}_{\alpha}$ and $\{111\}_{\alpha}$ habit planes, respectively $[9,22]$. According to the selected area diffraction (SAD) pattern (Fig. 3a, inset) and the orientation relationships of $\theta^{\prime}$ and $\mathrm{T}_{1}$ with the matrix, it could be concluded that the plate-like phases were $\mathrm{T}_{1}$ precipitates. Little evidence of $\theta^{\prime}$ precipitates was found primarily due to the extremely high $\mathrm{Li} / \mathrm{Cu}$ ratio of the studied alloy. A similar result was obtained by Decreus et al., who detected no signal of $\theta^{\prime}$ precipitates in AA2196

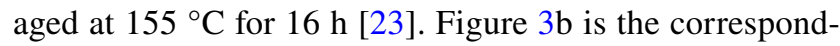
ing DF image. Some $\beta^{\prime} / \delta^{\prime}$ composite particles and a large number of $\delta^{\prime}$ phases (approximately $16.5 \mathrm{~nm}$ ) can be seen 

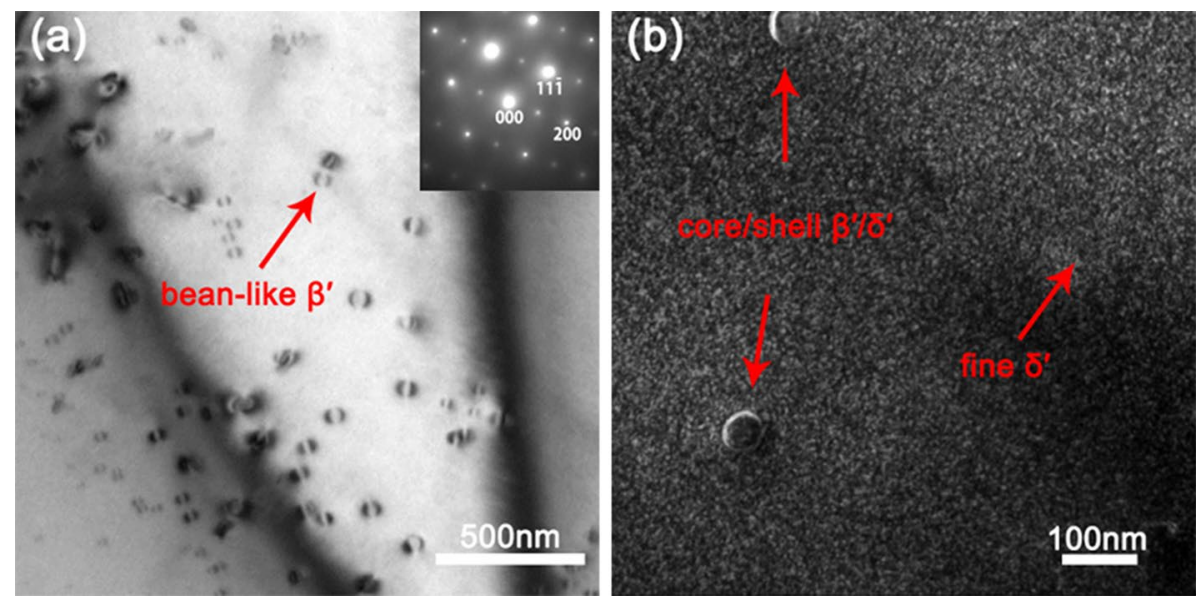

Fig. 2 TEM micrographs of the sample subjected to NA treatment: a BF image showing the $\beta^{\prime}-\mathrm{Al}_{3} \mathrm{Zr}$ phases with Ashby-Brown contrast feature; b DF image showing the $\beta^{\prime} / \delta^{\prime}$ composite particles and ultra-fine $\delta^{\prime}$ phases
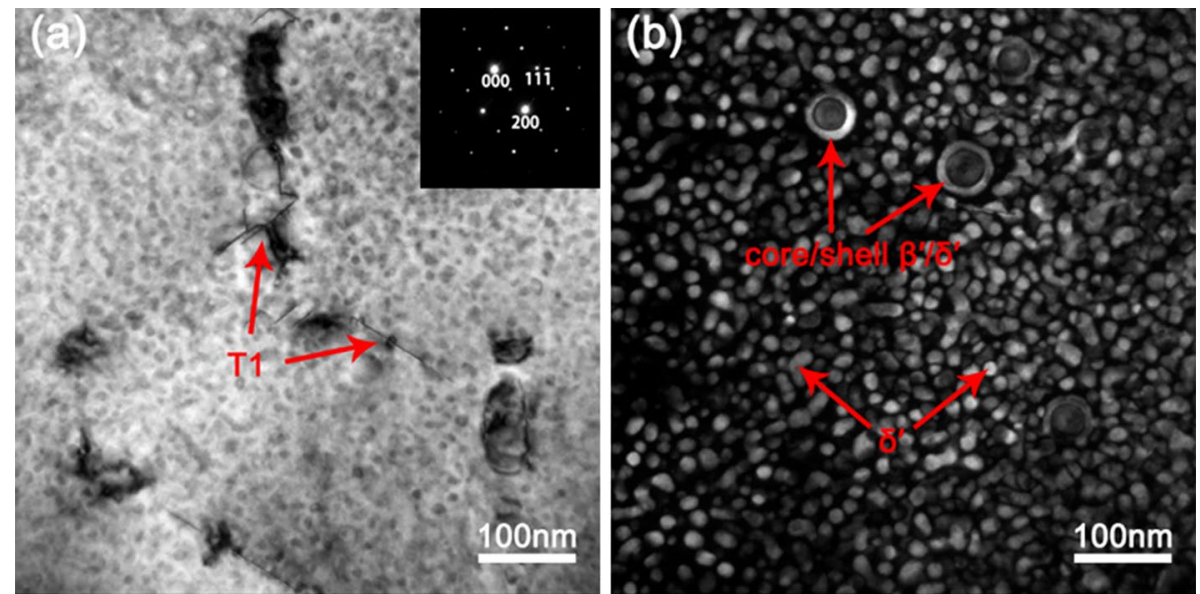

Fig. 3 TEM micrographs of the sample aged at $150{ }^{\circ} \mathrm{C}$ for $24 \mathrm{~h}$ : a $\mathrm{BF}$ image and the SAD pattern (inset) showing the $\mathrm{T}_{1}$ precipitates; $\mathbf{b} \mathrm{DF}$ image showing the $\beta^{\prime} / \delta^{\prime}$ composite particles and a large number of $\delta^{\prime}$ phases

in the aluminum matrix. The number density of $\delta^{\prime}$ particles was much higher than that of $\mathrm{Cu}$-rich precipitates, which is consistent with the ratio of these two intermetallic phases in alloy 8090 (2.5 wt\% Li, $1.3 \mathrm{wt} \% \mathrm{Cu}, 1.0 \mathrm{wt} \% \mathrm{Mg}, 0.12$ $\mathrm{wt} \% \mathrm{Zr}$ ) [9]. There are two reasons to explain this phenomenon. Firstly, owing to the extremely small relative atomic mass, the atomic percentage of $\mathrm{Li}(10.8$ at.\%) is much higher than that of $\mathrm{Cu}(0.8$ at.\%) in this studied alloy. Secondly, the lithium atom to vacancy binding energy is very strong [24]. Therefore, lithium could occupy most vacancies after quenching, which contributed to the nucleation and growth of $\delta^{\prime}$ particles and inhibited the formation of $\mathrm{Cu}$-rich precipitates by competition.

Figure $4 \mathrm{a}$ shows the $\mathrm{BF}$ image $(B=[011])$ of the sample aged at $160{ }^{\circ} \mathrm{C}$ for $24 \mathrm{~h}$. The number density of the platelike precipitates was increased to about $2523.6 \mu^{-3}$, but still in a small magnitude. The non-uniform distribution of
$\mathrm{Cu}$-rich precipitates is mainly due to the relatively low $\mathrm{Cu}$ content and the absence of dislocations in the cast alloy. Moreover, the precipitation of $\theta^{\prime}$ phase, as well as $\mathrm{T}_{1}$ phase, was detected. The higher temperature might promote the $\theta^{\prime}$ precipitation by accelerating the motion of $\mathrm{Cu}$ solute. Figure $4 \mathrm{~b}$ is the corresponding DF image, showing that the $\delta^{\prime}$ particles with an average diameter of $18.3 \mathrm{~nm}$ were distributed evenly in the matrix.

Figure $5 \mathrm{a}, \mathrm{b}$ presents the $\mathrm{BF}(B=[011])$ and $\mathrm{DF}$ images of the sample aged at $170{ }^{\circ} \mathrm{C}$ for $24 \mathrm{~h}$, respectively. As shown in Fig. 5a, the number density of $\mathrm{Cu}$-rich phases was increased obviously to about $4037.7 \mu \mathrm{m}^{-3}$ and most of these phases were $\mathrm{T}_{1}$. The diffraction spots and streaks related to $T_{1}$ precipitates in the SAD pattern (inset) also indicated the relatively high volume fraction of $\mathrm{T}_{1}$ precipitates as well. Further raised ageing temperature increased the kinetic energy of $\mathrm{Cu}$ atoms, promoting the nucleation 

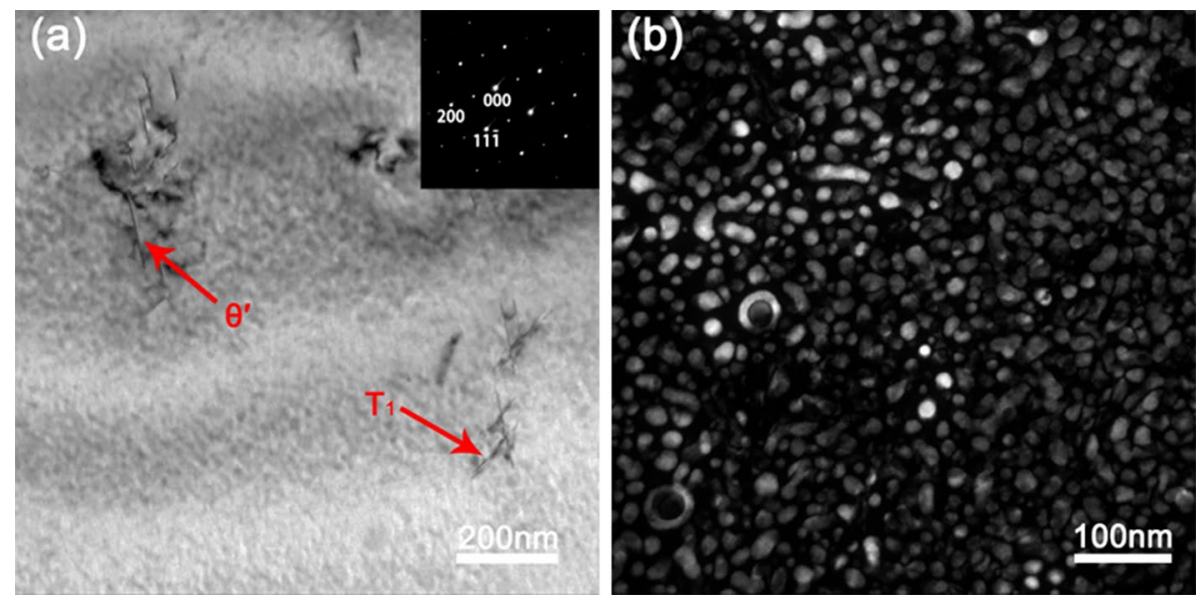

Fig. 4 TEM micrographs of the sample aged at $160{ }^{\circ} \mathrm{C}$ for $24 \mathrm{~h}$ : a BF image and the SAD pattern (inset) showing the non-uniform precipitation of $\mathrm{T}_{1}$ and $\theta^{\prime}$ phases; $\mathbf{b}$ DF image showing the evenly distributed $\delta^{\prime}$ phases
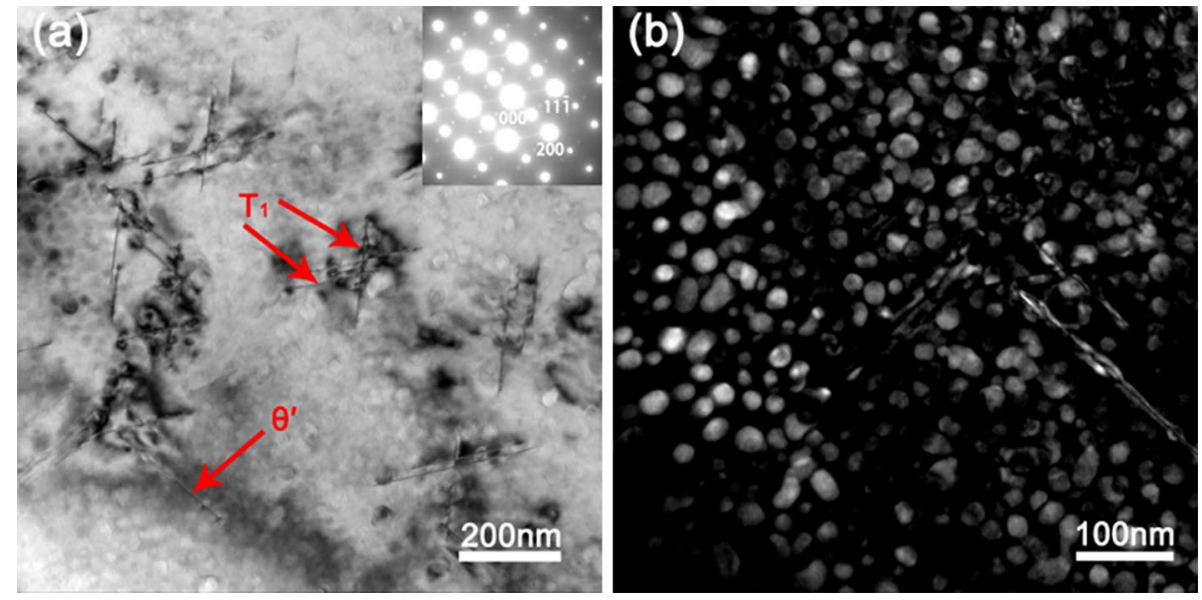

Fig. 5 TEM a BF, b DF images of the sample aged at $170^{\circ} \mathrm{C}$ for $24 \mathrm{~h}$

and growth of $\mathrm{Cu}$-rich precipitates. The average size of $\mathrm{T}_{1}$ precipitates at this temperature was measured to be $230.0 \mathrm{~nm}$ and the $\delta^{\prime}$ particles were coarsened to about $25.4 \mathrm{~nm}$ as shown in Fig. $5 \mathrm{~b}$.

As increasing the ageing temperature to $180{ }^{\circ} \mathrm{C}$, the precipitation of $\mathrm{Cu}$-rich phases was further intensified and the number density increased to about $4458.3 \mu \mathrm{m}^{-3}$ as shown in Fig. 6a. This BF image was viewed along $[011]_{\alpha}$. In this orientation, habit planes ( $\overline{1} 11)$ and (1 111$)$ are parallel to the beam direction, resulting in the narrowest image width for $\mathrm{T}_{1}$ phases (marked with " $\mathrm{T}_{1}$ ") on these matrix planes. However, another variant of $\mathrm{T}_{1}$ phases can also be found in Fig. 6a. These broad $\mathrm{T}_{1}$ images (marked with "A") correspond to $\mathrm{T}_{1}$ plates whose habits lie on (11 $\left.\overline{1}\right)$ and (111) matrix planes, which are equally inclined to the beam direction $\left(35.3^{\circ}\right)$ [25]. Figure $6 \mathrm{~b}$ is the DF image of the sample aged at $180{ }^{\circ} \mathrm{C}$ for $24 \mathrm{~h}$ taken using one superlattice spot. As can be seen, the mean size of $\delta^{\prime}$ particles was coarsened to about $31.8 \mathrm{~nm}$.

The BF micrograph of the sample aged at $190{ }^{\circ} \mathrm{C}$ for $24 \mathrm{~h}$ is shown in Fig. $7 \mathrm{a}(B=[011])$. The number density of $\mathrm{Cu}$-rich particles (mainly $\mathrm{T}_{1}$ ) was increased to about $4483.5 \mu^{-3}$, indicating a faint precipitation enhancement compared with the sample aged at $180{ }^{\circ} \mathrm{C}$ for $24 \mathrm{~h}$. However, the growth of $\mathrm{T}_{1}$ precipitates (above $500.0 \mathrm{~nm}$ ) was much more distinct. The nucleation of $\mathrm{T}_{1}$ precipitates was very difficult in the studied cast alloy due to the absence of dislocations [26]. In contrast, the growth of pre-existed $\mathrm{T}_{1}$ precipitates was much easier, resulting in the extremely high aspect ratio of $\mathrm{T}_{1}$ phases. The high ageing temperature also accelerated the growth of $\delta^{\prime}$ particles, which were coarsened to approximately $35.4 \mathrm{~nm}$ as shown in Fig. $7 \mathrm{~b}$.

The microstructures of the sample subjected to TS treatment are given in Fig. 8. In the BF image (Fig. 8a, $B=$ 

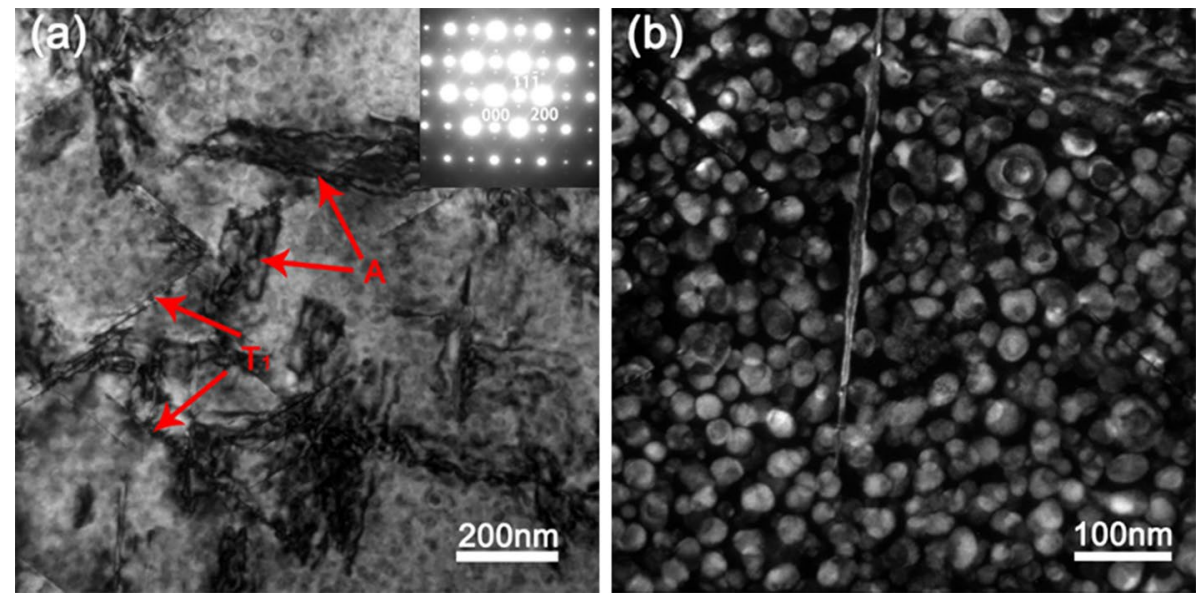

Fig. 6 TEM micrographs of the sample aged at $180{ }^{\circ} \mathrm{C}$ for $24 \mathrm{~h}$ : a BF image and the SAD pattern (inset) showing the two kinds of $\mathrm{T}_{1}$ variants; $\mathbf{b}$ DF image
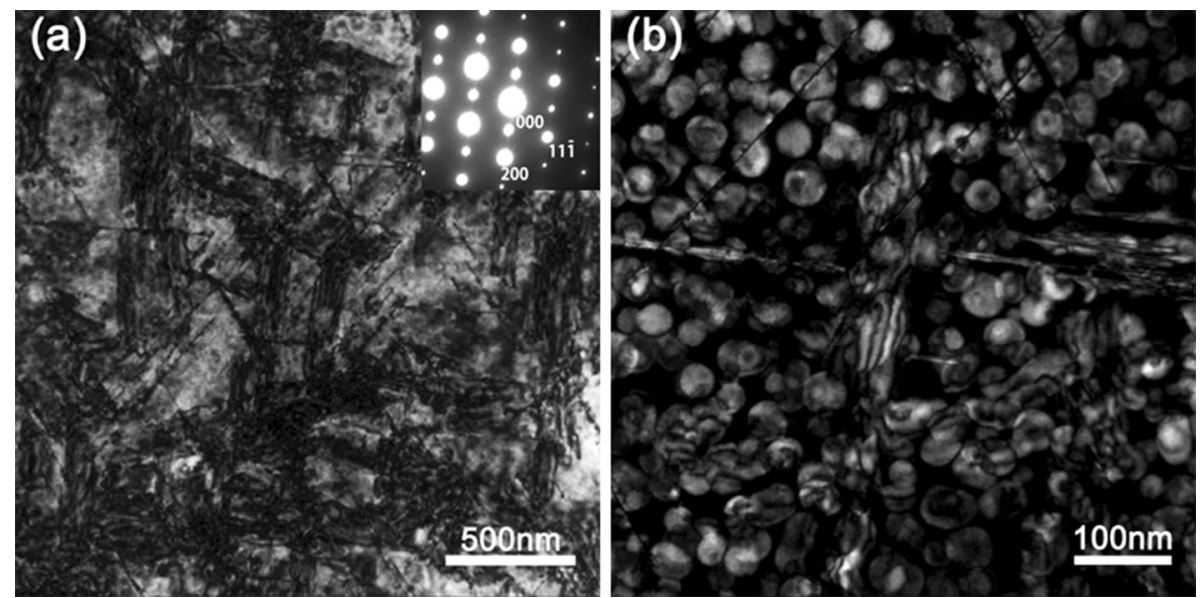

Fig. 7 TEM a BF, b DF images of the sample aged at $190{ }^{\circ} \mathrm{C}$ for $24 \mathrm{~h}$ showing the coarsened $\mathrm{T}_{1}$ and $\delta^{\prime}$ phases

[001]), some needle-like phases were perpendicular to each other, showing that a certain amount of $\theta^{\prime}$ particles precipitated from the matrix during the TS treatment. A pre-age stretch coupled with a duplex low-to-high temperature ageing schedule was shown to be able to substantially increase the ductility and fracture toughness of X2095 wrought Al-Li alloy [27]. The objective of this two-step (low-to-high) artificial ageing treatment is to promote the nucleation of precipitates in the first step and coarsen the precipitates in the second step [28]. Although there was not any pre-age deformation in this studied cast alloy, the first stage of the duplex ageing treatment at a low temperature $\left(120^{\circ} \mathrm{C}\right)$ was proved to be able to enhance the precipitation driving force of $\mathrm{Cu}$-rich phases in the same way, resulting in an increased number density of $\theta^{\prime}$ particles $\left(5833.3 \mu \mathrm{m}^{-3}\right)$. The mean size of $\delta^{\prime}$ particles in Fig. 8b (DF image of the sample subjected to TS treatment) was measured to be about $19.4 \mathrm{~nm}$, slightly larger than those phases in Fig. $4 \mathrm{~b}(18.3 \mathrm{~nm})$. These $\delta^{\prime}$ particles usually exhibit a regular spherical shape, but nonespherical morphologies were also observed (marked with "B" in Fig. 8b) in this research. This phenomenon could be explained as the coalescence of particles in consideration of the huge $\delta^{\prime}$ volume fraction. Besides, some $\theta^{\prime}$ precipitates were surrounded by $\delta^{\prime}$ phases (marked with "C") as shown in the corresponding partial enlarged drawing, which revealed the interaction between $\theta^{\prime}$ and $\delta^{\prime}$ precipitates.

\subsection{Mechanical properties}

To investigate the influence of different ageing treatments on mechanical properties of cast $\mathrm{Al}-3 \mathrm{Li}-2 \mathrm{Cu}-0.2 \mathrm{Zr}$ alloy, tensile tests were conducted. The ultimate tensile strength (UTS), yield strength (YS), elongation (EL) and representative engineering stress-strain curves of the studied 

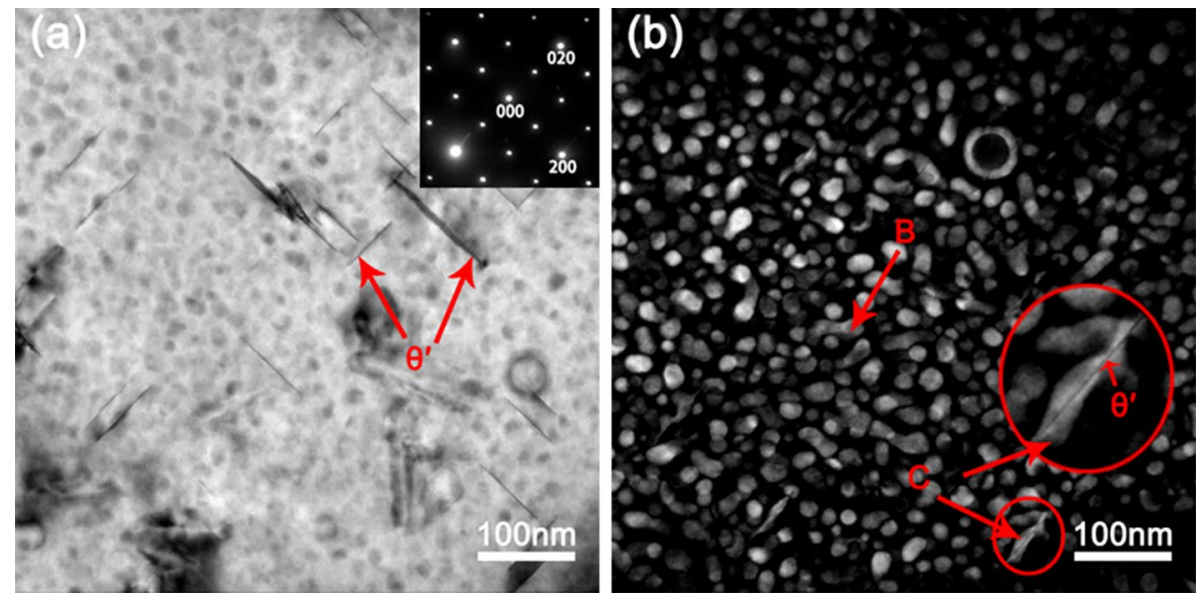

Fig. 8 TEM micrographs of the sample subjected to TS treatment: a BF image and the SAD pattern (inset) showing the needle-like $\theta^{\prime}$ particles perpendicular to each other; $\mathbf{b}$ DF image and the partial enlarged drawing showing the none-spherical $\delta^{\prime}$ (marked with "B") and the interaction between $\theta^{\prime}$ and $\delta^{\prime}$ precipitates (marked with "C")

alloy under different ageing conditions are shown in Fig. 9. As can be seen in Fig. 9a, the YS, UTS and EL of the alloy in the as-quenched state (T4) were $108 \mathrm{MPa}, 290 \mathrm{MPa}$ and $23.2 \%$, respectively. After the natural ageing treatment for 6 months, the YS was increased to $145 \mathrm{MPa}$ together with a $10 \mathrm{MPa}$ UTS drop. It is reasonable to attribute this YS improvement to the precipitation of ultra-fine $\delta^{\prime}$ phases as shown in Fig. 2b, while the slight decrease in UTS was a result of the lower ductility compared with the as-quenched state. For the single-stage artificial ageing treatments, the YS and UTS increased with the increase in ageing temperature, while the ductility showed an opposite trend. Based on the above TEM results, the strength increment of samples aged at $150{ }^{\circ} \mathrm{C}$ or $160{ }^{\circ} \mathrm{C}$ should be mainly attributed to the growth of $\delta^{\prime}$ precipitates since the percentage of $\mathrm{Cu}$-rich phases was still extremely low. The hardening of these metastable coherent $\delta^{\prime}$ phases is associated with ordering when the leading dislocation forms an antiphase boundary and the next paired dislocation restores the order [9]. The number densities of $\mathrm{Cu}$-rich phases (mainly $\mathrm{T}_{1}$ ) in samples aged at $170{ }^{\circ} \mathrm{C}, 180{ }^{\circ} \mathrm{C}$ and $190{ }^{\circ} \mathrm{C}$ reached a high magnitude as shown in the above TEM micrographs. It is well known that among various precipitates in $\mathrm{Al}-\mathrm{Li}-\mathrm{Cu}$ alloys, the maximum critical resolved shear stress (CRSS) increment is produced by $\{111\}_{\alpha}$ precipitate plates [29]. It means that $T_{1}$ phase is more effective than $\delta^{\prime}$ phase in strengthening $\mathrm{Al}-\mathrm{Li}-\mathrm{Cu}$ alloys. Apart from the growth of $\delta^{\prime}$ phases, the high strength of the sample aged at $170{ }^{\circ} \mathrm{C}, 180{ }^{\circ} \mathrm{C}$ or $190{ }^{\circ} \mathrm{C}$ was ascribed to the high number density of $\mathrm{Cu}$-rich precipitates (mainly $\mathrm{T}_{1}$ ) to a great extent. Unfortunately, $\delta^{\prime}$ particles have been known to favor the localization of plastic flow, shear banding and early fracture [30]. With the increase in mean $\delta^{\prime}$ particle size, planar slip accompanied
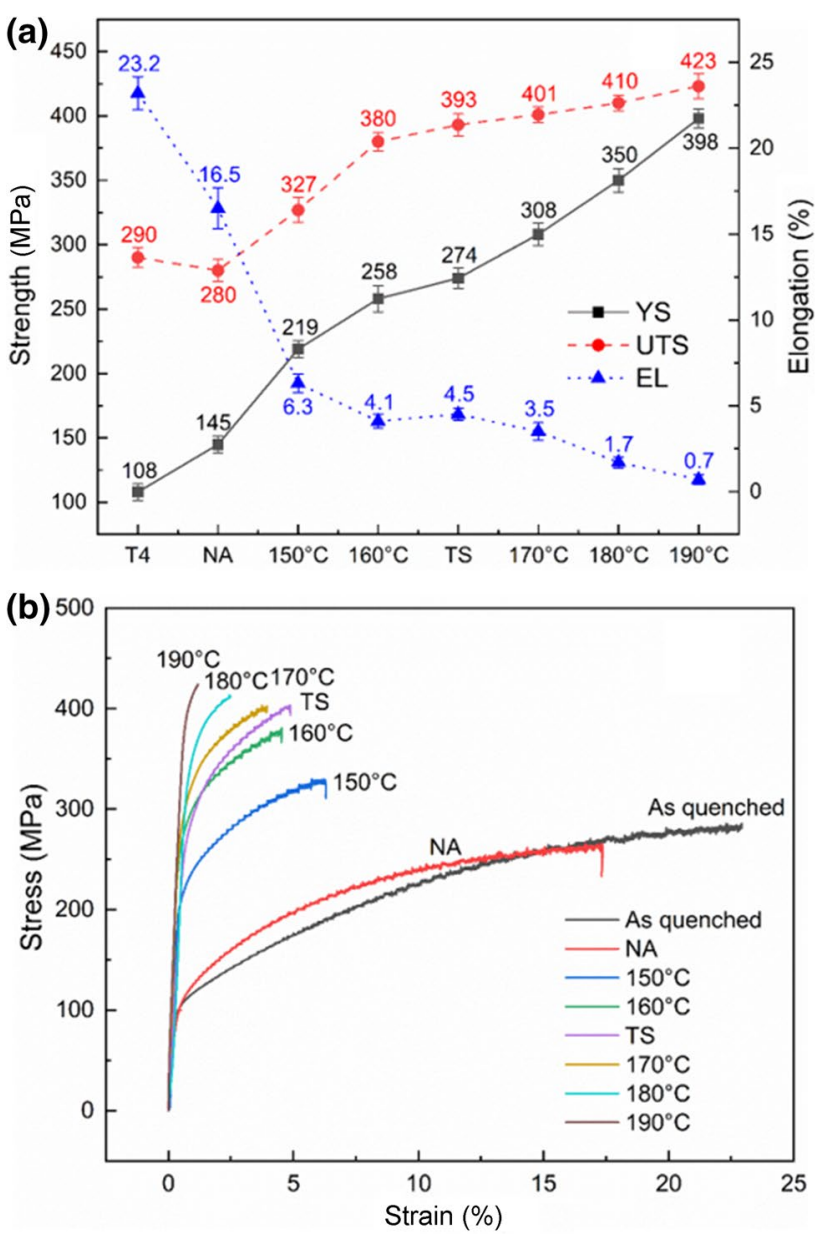

Fig. 9 Mechanical properties a and representative engineering stressstrain curves $\mathbf{b}$ of cast $\mathrm{Al}-3 \mathrm{Li}-2 \mathrm{Cu}-0.2 \mathrm{Zr}$ alloy after different ageing treatments 

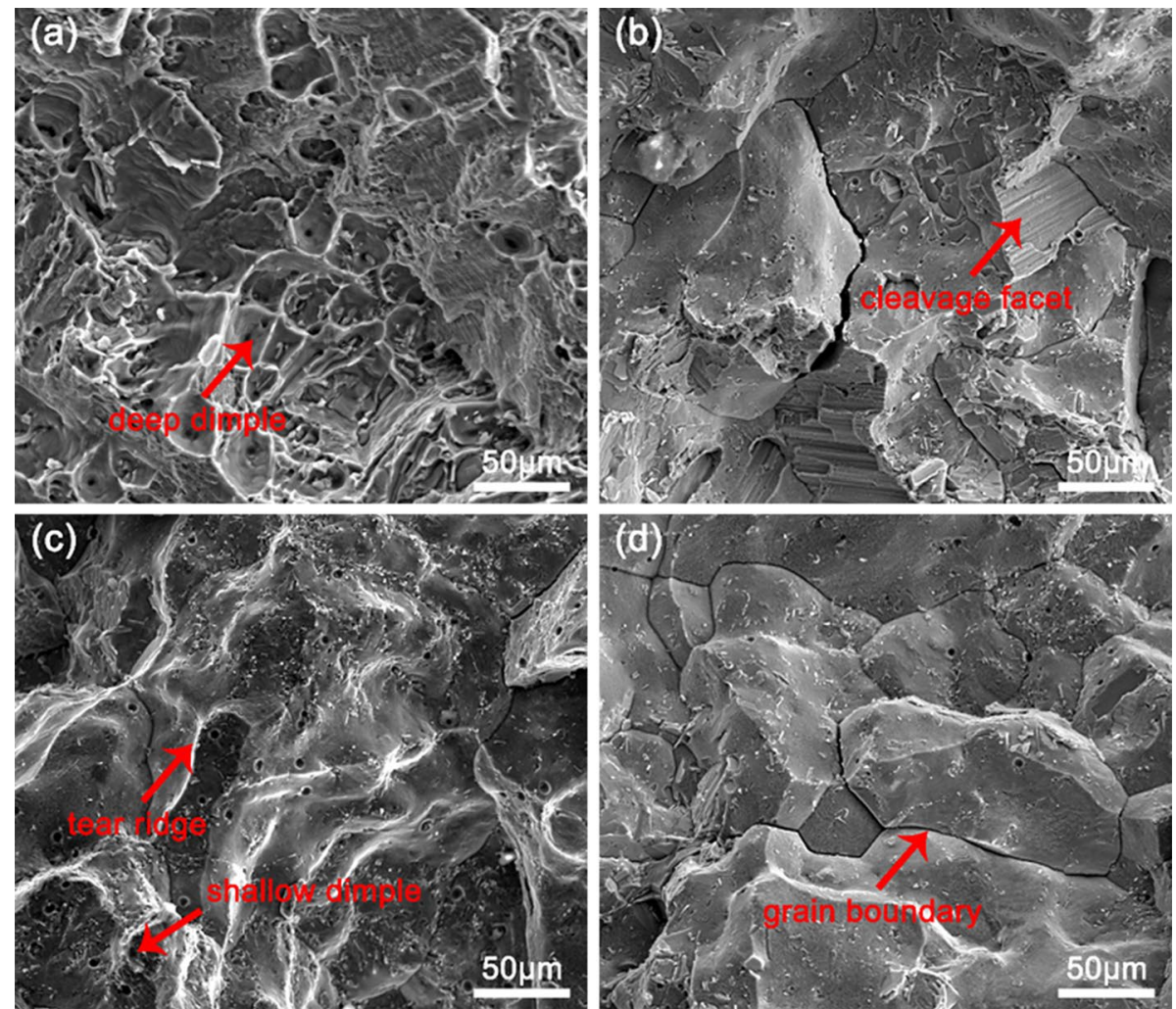

Fig. 10 Typical fracture morphologies of the samples subjected to a NA; b $160{ }^{\circ} \mathrm{C} \times 24 \mathrm{~h} ; \mathbf{c} \mathrm{TS} ; \mathbf{d} 190{ }^{\circ} \mathrm{C} \times 24 \mathrm{~h}$ ageing treatments

by the shearing of $\delta^{\prime}$ particles and the stress concentration at grain boundaries intensified, resulting in the continuously deteriorated ductility.

It is noteworthy that the alloy subjected to TS treatment shows an improvement in both strength and ductility compared with the corresponding single-stage ageing treatment $\left(160{ }^{\circ} \mathrm{C}\right.$ for $\left.24 \mathrm{~h}\right)$. On the one hand, the increased number density of $\theta^{\prime}$ and the increased mean particle size of $\delta^{\prime}$ were responsible for the strength improvement. On the other hand, more attention should be paid to the improvement in ductility. It has been found that the most effective method of reducing strain location is to minimize the slip length [31]. The grain size is taken as the slip length for the material with microstructure comprised of pervasive shearable precipitates [32]. For microstructure containing both shearable and non-shearable precipitates, the slip length can be considered as the interparticle distance between the non-shearable precipitates [33]. Unlike the $\delta^{\prime}$ particle, plate-shaped $\mathrm{T}_{1}$ and $\theta^{\prime}$ were reported to be non-shearable particles [34]. Therefore, the greater ductility of the duplex-aged alloy in this study was attributed to the reduced slip length caused by the increased number density of $\theta^{\prime}$ plates, which overwhelmed the adverse effect of the slight $\delta^{\prime}$ particles growth.

\subsection{Fractography}

Figure 10 presents the typical tensile-ruptured surface morphologies of samples subjected to different ageing treatments in a scanning electron microscope. The fracture surface of the sample in the NA state (Fig. 10a) was covered by deep dimples, indicating a typical ductile fracture feature. The underneath mechanism of this ductile fracture can be explained by the classical void growth model, which divides the fracture process into three steps: void initiation, growth and coalescence [35]. Some cleavage facets instead of dimples emerged on the fracture surface of sample aged at $160{ }^{\circ} \mathrm{C}$ (Fig. 10b), which was consistent with the cleavage fracture feature. However, when a duplex ageing treatment (TS) was applied, some tear ridges coupled with numerous shallow dimples were formed as shown in Fig. 10c. This feature further indicated the higher number density of precipitates in the TS state compared with the corresponding single-stage ageing treatment $\left(160{ }^{\circ} \mathrm{C}\right)$. Increasing the ageing temperature to $190{ }^{\circ} \mathrm{C}$, the fracture surface was characterized mainly by grain boundaries (Fig. 10d), suggesting the intergranular brittle fracture feature, which coincided with the poor ductility. 


\section{Conclusions}

The influence of different ageing treatment parameters on cast $\mathrm{Al}-3 \mathrm{Li}-2 \mathrm{Cu}-0.2 \mathrm{Zr}$ alloy was systematically studied via SEM, TEM observations and tensile tests. The following conclusions could be drawn:

1. For the single-stage artificial ageing treatments from 150 to $190{ }^{\circ} \mathrm{C}$, the YS and UTS increased constantly due to the growth of $\delta^{\prime}-\mathrm{Al}_{3} \mathrm{Li}$ precipitates and the increased number density of $\mathrm{Cu}$-rich precipitates (mainly $\mathrm{T}_{1}$ ).

2. With the increase in ageing temperature, planar slip accompanied by the shearing of $\delta^{\prime}$ particles and the stress concentration at grain boundaries intensified, inducing the continuously decreased ductility.

3. The duplex low-to-high ageing treatment could increase the number density of $\theta^{\prime}$ plates, reduce the slip length and result in a greater ductility in addition to an increased strength compared with the corresponding single-stage ageing treatment.

Acknowledgements This work was financially supported by the National Natural Science Foundation of China (Nos. 51871148 and 51821001) and the United Fund of National Department of Education and Equipment Development (No. 6141A02033245).

\section{References}

[1] R. Rajan, P. Kah, B. Mvola, J. Martikainen, Rev. Adv. Mater. Sci. 44, 383 (2016)

[2] L. Wu, Y. Chen, X. Li, N. Ma, H. Wang, Mater. Sci. Eng. A 743, 741 (2019)

[3] Q. Chen, S. Lin, C. Yang, C. Fan, H. Ge, Acta Metall. Sin. (Engl. Lett.) 29, 1081 (2016)

[4] S. Seshan, T.S. Srivatsan, Mater. Manuf. Processes 5, 109 (1990)

[5] Y. Ma, H. Wu, X. Zhou, K. Li, Y. Liao, Z. Liang, L. Liu, Corros. Sci. 158 (2019).

[6] X. Zhang, L. Zhang, G. Wu, J. Sun, M. Rong, C. Hsieh, Y. Yu, Mater. Charact. 142, 223 (2018)

[7] Q. Chen, S. Lin, C. Yang, C. Fan, Acta Metall. Sin. (Engl. Lett.) 29, 367 (2016)

[8] X. Jin, B. Fu, C. Zhang, W. Liu, Acta Metall. Sin. (Engl. Lett.) 28, $1149(2015)$
[9] S.Y. Betsofen, V.V. Antipov, M.I. Knyazev, Russ. Metall. 4, 326 (2016)

[10] X. Wang, G. Li, J. Jiang, W. Shao, L. Zhen, Mater. Sci. Eng. A 742, 138 (2019)

[11] X. Zhang, L. Zhang, G. Wu, C. Shi, J. Zhang, J. Mater. Sci. 54, 791 (2018)

[12] J. Ma, D. Yan, L. Rong, Y. Li, Acta Metall. Sin. (Engl. Lett.) 28 , 454 (2015)

[13] H. Sidhar, N.Y. Martinez, R.S. Mishra, J. Silvanus, Mater. Des. 106, 146 (2016)

[14] S. Zhang, W. Zeng, W. Yang, C. Shi, H. Wang, Mater. Des. 63, $368(2014)$

[15] C. Shi, L. Zhang, G. Wu, X. Zhang, A. Chen, J. Tao, Mater. Sci. Eng. A 680, 232 (2017)

[16] A. Chen, L. Zhang, G. Wu, Y. Peng, Y. Li, J. Mater. Res. 31, 250 (2016)

[17] M. Rong, L. Zhang, G. Wu, W. Li, X. Zhang, J. Sun, W. Ding, Trans. Nonferrous Met. Soc. China 29, 1375 (2019)

[18] A.T. Chen, G.H. Wu, L. Zhang, X.L. Zhang, C.C. Shi, Y.L. Li, Mater. Sci. Eng. A 677, 29 (2016)

[19] L.V. Tarasenko, N.I. Kolobnev, L.B. Khokhlatova, Met. Sci. Heat Treat. 50, 80 (2008)

[20] Y. Wang, Z. Li, T. Yu, A. Medjahed, R. Wu, L. Hou, J. Zhang, X. Li, M. Zhang, Adv. Eng. Mater. 20, 1700898 (2018)

[21] Y. Wang, Z. Zhang, R. Wu, J. Sun, Y. Jiao, L. Hou, J. Zhang, X. Li, M. Zhang, Mater. Sci. Eng. A 745, 411 (2019)

[22] L.B. Khokhlatova, N.I. Kolobnev, M.S. Oglodkov, E.D. Mikhaylov, Metallurgist 56, 336 (2012)

[23] B. Decreus, A. Deschamps, F. De Geuser, P. Donnadieu, C. Sigli, M. Weyland, Acta Mater. 61, 2207 (2013)

[24] J.W. Martin, Annu. Rev. Mater. Sci. 18, 101 (1988)

[25] W.A. Cassada, G.J. Shiflet, E.A. Starke, Metall. Trans. A 22, 287 (1991)

[26] J. Li, Z. Ye, D. Liu, Y. Chen, X. Zhang, X. Xu, Z. Zheng, Acta Metall. Sin. (Engl. Lett.) 30, 133 (2016).

[27] C.P. Blankenship, E.A. Starke, Acta Metall. Mater. 42, 845 (1994)

[28] M. Romios, R. Tiraschi, C. Parrish, H.W. Babel, J.R. Ogren, O.S. Es-Said, J. Mater. Eng. Perform. 14, 641 (2005)

[29] A. Chen, Y. Peng, L. Zhang, G. Wu, Y. Li, Mater. Charact. 114, 234 (2016)

[30] A. Deschamps, B. Decreus, F. De Geuser, T. Dorin, M. Weyland, Acta Mater. 61, 4010 (2013)

[31] A.A. Csontos, E.A. Starke, Int. J. Plast. 21, 1097 (2005)

[32] V.W.C. Kuo, E.A. Starke, Metall. Trans. A 16, 1089 (1985)

[33] P.J. Gregson, H.M. Flower, Acta Metall. 33, 527 (1985)

[34] M. Lewandowska, J. Mizera, J.W. Wyrzykowski, Mater. Charact. 45, 195 (2000)

[35] N.D. Alexopoulos, E. Migklis, A. Stylianos, D.P. Myriounis, Int. J. Fatigue 56, 95 (2013) 